\section{ИСКОННОЕ НАЗВАНИЕ АРЖААНА КУНДУСТУГ - БУЛУК}

\author{
Надежда М. Очур \\ Тувинский институт гуманитарных и \\ прикладных социально-экономических \\ исследований, Российская Федерация
}

\section{BULUK AS THE ORIGINAL NAME OF ARZHAAN KUNDUSTUG}

\author{
Nadezhda M. Ochur \\ Tuvan Institute for the Humanities and \\ Applied Socioeconomic Studies, \\ Russian Federation
}

В статье анализируется проблема переименования аржаана, находящегося на правом берегу Енисея, напротив левобережных дач г. Кызыла, которого переименовали в Кундустуг в 2004 2. несмотря на то, что исконным его названием был - Булук.

Приведены описания значения слова «булук» на основе словарей тувинско$2 о$ языка (толкового, этимологического, топонимического); представлены толкования слова местными жителями, которые были опрошены автором

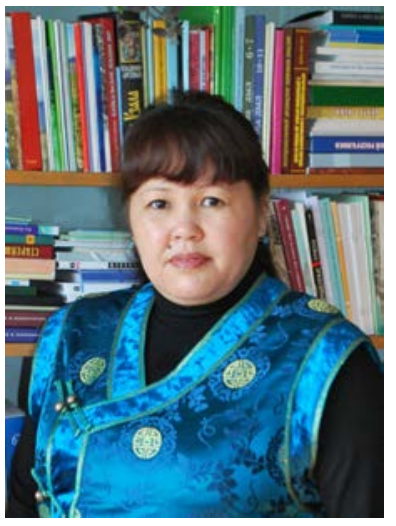

This paper investigates the original name of the holy spring Buluk that is located on the right bank of the Yenisei river, not far from the city of Kyzyl. In 2004, the holy spring was renamed Kundustug, although its original name had been Buluk.

We provide vocabulary definitions of 'buluk' from etymological, toponymical and other dictionaries of Tuvan and counterpoise them with interpretations obtained from local population surveyed in 2011-2012. The author points out the connection between geographical features and the name of holy spring Buluk and статьи в 2011-2012 г2. Подчеркнуто, что название отражает естественно-географические особенности аржаана: зимой отдельные истоки аржаана не замерзают до кониа, продолжают выбиваться из земли, превращаются в лёд и образуют наледь, которая до самого конца зимы увеличивается в размерах.

Проанализированы текстовые и картографические документальные источники, подтверждающие историческое название аржаана Булук. Представлены микротопонимы, образованные от данного топонима: Булук кыры (Над Булуком), Булук үстү (Верховье Булука), Булук адаа (Низовье Булука). Местность аржаана Булук всегда была частью земель села Ээрбек, в настоящее время входит в земли сельского поселения Ээрбек Кызылского кожууна.

Подчеркнута важность сохранения исконных названий географических объектов, которые заклюanalyses written and cartographic documentary sources that confirms the historical name of holy spring. The name reflects the natural features of the arzhaan, which does not freeze completely in winters, and some springs form icing which keeps increasing until spring.

The paper also examines derivative microtoponyms. The location on the north side of the holy spring is called Buluk kyry (Above Buluk), while a place up the Yenisei river called Buluk ustu (Upstream Buluk) and down the river, Buluk Adaa (Downstream Buluk). The area of holy spring Buluk has always been and remains part of the Eerbek village, which, in its turn, currently is part of Kyzyl kozhuun.

The article concludes by emphasizing the importance of preserving the original names of

Очур Надежда Маaдыр-ооловна - заведующая научной библиотекой Тувинского института гуманитарных и прикладных социально-экономических исследований. Адрес: 667000, Россия, г. Кызыл, ул. Кочетова, д. 4. Тел.: +7 (913) 351-03-72. Эл. адрес: ochur72nadia@mail.ru

Ochur Nadezhda Maadyr-oolovna, Head of Research Library, Tuvan Institute for the Humanities and Applied Socioeconomic Studies. Postal address: Bldg 4, Kochetova St., 667000, Kyzyl, Russian Federation. Tel.: +7 (913) 351-03-72. E-mail: ochur72nadia@mail.ru 
чают в себе уникальную культурно-историческую информацию. В настоящее время жителями села Ээрбек и чабанами Биче-Баян-Кола ведется работа по восстановлению исконного исторического названия аржаана.

Ключевые слова: топонимия; Тува; топоним; микротопоним; тувинский язык; аржаан; Ээрбек; Биче-Баян-Кол; Булук; Кундустуг geographical objects, which contain unique cultural and historical information. At the moment, the village residents of Eerbek and shepherds of Biche Bayan-Kol are working on restoration of native historical name of holy spring.

Keywords: toponymics; Tuva; toponym; microtoponym; Tuvan language; arzhaan; holy spring, Eerbek; Biche-Bayan-Kol; Buluk; Kundustug

\section{Введение}

Топонимы тесно связаны с историей и культурой народов, давших названия природным объектам, окружающим их. Поэтому многие путешественники и открыватели новых земель при присвоении названия географическому объекту учитывали в первую очередь название, которое уже было дано местными жителями. Кроме того, данное правило всегда было закреплено соответствующими законодательными актами. В настоящее время в Российской Федерации таковым является Федеральный закон от 18 декабря 1997 г. № 152-Ф3 «О наименованиях географических объектов» (с изменениями и дополнениями). Из него следует, что географические названия объектов должны основываться на уже существующих документальных источниках или микротопонимах, которые являются связующей нитью между прошлым и будущим местного населения. И, тем не менее, имеются случаи несоблюдения вышеназванных норм, в том числе в Туве.

Цель статьи заключается в том, чтобы, основываясь на документальных источниках и устных рассказах местных жителей, которые были собраны нами в 2011-2012 гг., обосновать: историческим названием аржаана, т. е. водного источника, Кундустуг является Булук.

\section{Месторасположение аржаана}

С 2004 г. аржаан Булук, находящийся на правом берегу реки Улуг-Хем (Енисей), напротив левобережных дач г. Кызыла - столицы Тувы, был переименован в «Кундустуг». Сразу возникли вопросы. Вода этого аржаана из недр земли забила только в 2004 г.? Или о наличии на этом месте целебного источника узнали только в 2004 г.?..

Территориально местность, где находится аржаан Булук, входит в земли сельского поселения Ээрбек Кызылского кожууна. Коренными жителями с. Ээрбек являются представители родоплеменной группы оюн, чьи предки селились в северных частях Танды-Уула, а иногда кочевали и на южные ее 
склоны, и потому территория, в которую входит с. Ээрбек, исторически является родовыми землями оюнаров.

Как свидетельствуют научные изыскания многих исследователей и исторические документы, оюнары не являются пришлым народом. Они постоянно проживали здесь и считались потомками тех древних племен, которые с XVIIXIX вв. кочевали на этой территории (Потанин, 1883; Катанов, 2011; Сафьянов, 2012; Маннай-оол, 2004). В ХХ в. к оюнарскому роду стали относится земли, на которых сегодня находятся: г. Кызыл, территория Тандынского, Кызылского кожуунов, в том числе местность Шоол, территория с. Ээрбек, со всеми прилегающими к нему землями, а также земли сумонов Усть-Элегест, Межегей, Кочетово, Чал-Кежиг и т. д.

К территории с. Ээрбек исконно относились земли, где непосредственно располагается с. Ээрбек, а также источник Булук, верховья р. Ээрбек, местность Төгэ баары ${ }^{1}$. Поэтому столетиями дорога, пролегающая на восток от Ээрбека, проходила через Булук. К местности, где расположен аржаан Булук, также имели непосредственное отношение и роды салчаков и маады, кочевавшие по местности Биче-Баян-Кол Пий-Хемского кожууна, которая соседствует с землями с. Ээрбек.

\section{Значение названия Булук}

По рассказам коренных жителей Ээрбека и чабанов Биче-Баян-Кола: Карашпая Оюна ${ }^{2}$ (1874-1934), Сотпуй-оола Карашпая ${ }^{3}$ (1903-1979), Шыырапа Оюна ${ }^{4}$ (1909-1985), Удумбараа Оюна ${ }^{5}$ (1911-1982), Василия Уйнукая (1920-

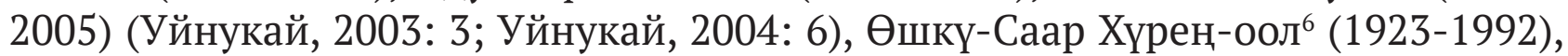
Эрээдар Өпей-оолㄱ (1924-2000), Чолдак-оола Сандыя ${ }^{8}$ (1939-2011), а также их потомков: Чочай Удумбараа (1934-2017), Михаила Дондупа ${ }^{10}$ (1941 г. p.), Демир-

\footnotetext{
1 Уйнукай В. К. Шагда Ээрбектин девискээринде черлернин шын аттары. (Личный архив Уйнукай В. К., д. 9) [без даты]. Личный архив В. К. Уйнукай хранится у Е. А. Опей-оол с 2005 г.

${ }^{2}$ Информатор Е. А. Опей-оол, внучка Карашпая Оюна. Запись сделана в 2011 г. Хранится в личном архиве автора статьи.

${ }_{3}^{3}$ Информатор Е. А. Опей-оол, племянница Сотпуй-оола Карашпая. Запись сделана в 2011 г. Хранится в личном архиве автора статьи.

${ }^{4}$ Информатор Е. А. Опей-оол, дочь Шыырапа Оюна. Запись сделана в 2011 г. Хранится в личном архиве автора статьи.

${ }^{5}$ Информатор Т. А. Удумбараа, дочь Удумбараа Оюна. Запись сделана в 2011 г. Хранится в личном архиве автора статьи.

${ }^{6}$ Информатор В. А. Хурен-оол, сын Өшкү-Саар Хүрең-оол. Запись сделана в 2011 г. Хранится в личном архиве автора статьи.

${ }^{7}$ Информатор И. П. Опей-оол, дочь Эрээдар Өпей-оол. Запись сделана в 2011 г. Хранится в личном архиве автора статьи.

${ }^{8}$ Информаторы Е. А. Опей-оол, Н. Ч. Сандый. Запись сделана в 2011 г. Хранится в личном архиве автора статьи. ${ }^{9}$ Информатор Ч. А. Удумбараа, уроженка с. Ээрбек Кызылского кожууна. Запись сделана в 2011 г. Хранится в личном архиве автора статьи.

${ }^{10}$ Информатор М. В. Дондуп, уроженец с. Ээрбек Кызылского кожууна. Запись сделана в 2011 г. Хранится в личном архиве автора статьи.
} 
оола Дотпаа ${ }^{1}$ (1942 г. р.), Биче-оола Амырдаa ${ }^{2}$ (1946 г. р.), Ираиды Опей-оол ${ }^{3}$ (1947 г. р.), Екатерины Опей-оол ${ }^{4}$ (1947 г. р.), Валерия Хүрен-оола ${ }^{5}$ (1958 г. р.) этот аржаан издревле имел название Булук.

Исторически представители родов оюн, салчак, маады пользовались водой этого источника, считали его священным и потому проводили здесь обряды освящения. Наряду с вышеназванными местными родами этому источнику оказывали своё почтение и другие жители Тувы, а также путешественники, чьи пути пролегали через эти земли, непременно замечали этот источник.

Необходимо сказать, что такое название этому аржаану - Булук - дано не случайно.

В «Тувинско-русском словаре» слово булук переводится как 'наледь, кромка льда’ (Тувинско-русский словарь, 1968: 122). Аналогичный перевод дан этому слову Б.К. Ондар, составителем словарей гидронимов и топонимов Тувы

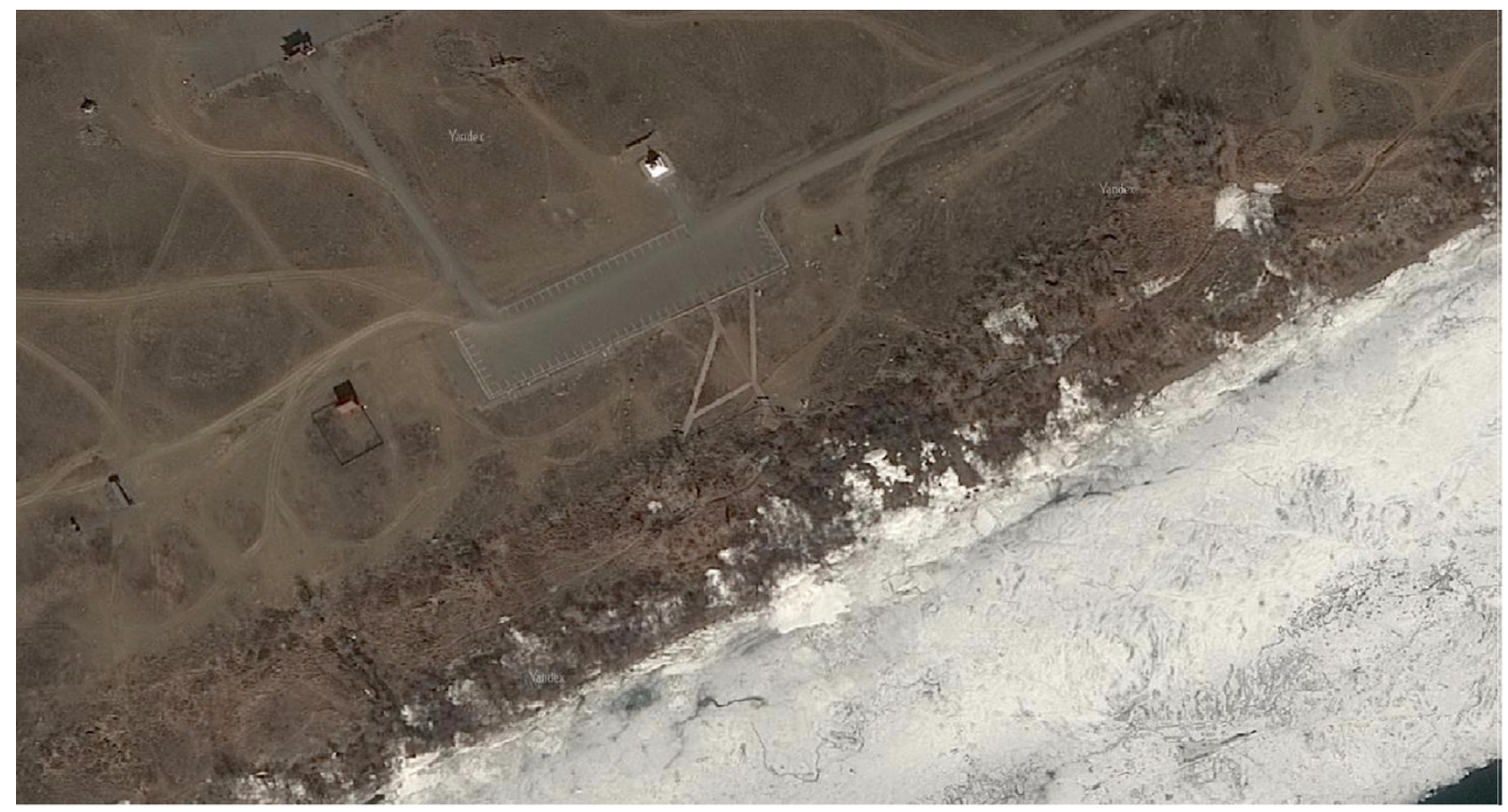

Рис. 1. Аржаан Булук в апреле, вид из космоса. Спутниковый снимок 2012 г. сервиса Яндекс-Карты. Pic. 1. Arzhaan Buluk in April, a view from space. Satellite photo, 2012, courtesy of Yandex.Maps.

\footnotetext{
${ }^{1}$ Информатор Д. С. Дотпаа, уроженец местечка Биче-Баян-Кол с. Сесерлиг Пий-Хемского кожууна. Запись сделана в 2012 г. Хранится в личном архиве автора статьи.

${ }^{2}$ Информатор Б. А. Амардаа, уроженец с. Ээрбек Кызылского кожууна. Запись сделана в 2011 г. Хранится в личном архиве автора статьи.

${ }^{3}$ Информатор И. П. Опей-оол, уроженка с. Ээрбек Кызылского кожууна. Запись сделана в 2011 г. Хранится в личном архиве автора статьи.

${ }^{4}$ Информатор Е. А. Опей-оол, уроженка с. Ээрбек Кызылского кожууна. Запись сделана в 2011 г. Хранится в личном архиве автора статьи.

${ }^{5}$ Информатор В. А. Хурен-оол, уроженец с. Ээрбек Кызылского кожууна. Запись сделана в 2011 г. Хранится в личном архиве автора статьи.
} 
(Ондар, 2007: 29). В «Толковом словаре тувинского языка» в толковании слова «булук» написано «Дош кырының суу, ооң кырында доңган дош» и переведено как 'наледь' (Толковый ..., 2003: 313), в «Этимологическом словаре тувинского языка» Б. И. Татаринцев пишет следующее «Булук - пулуг ... связаны с образной (глагольной) основой, обозначающей нечто изогнутое, раздувшееся...» (Татаринцев, 2000: 292).

Предки тувинцев, жившие в рассматриваемой нами местности, называя аржаан Булуком, учли его естественно-географическую особенность, т. е. его естественное состояние в осенне-зимне-весеннее время. Зимой даже в сильные морозы отдельные истоки аржаана не замерзают до конца, продолжают выбиваться из земли и только на поверхности земли превращаются в лёд и образуют наледь, которая с каждым днём и до самого конца зимы увеличивается в размерах. В зимнее и весеннее время любой посетитель аржаана может наблюдать это удивительное явление природы.

Особенно хорошо наледь видна после таяния снега в конце марта и апреле, а иногда и в начале мая с левого берега Енисея, что также отмечали в своих дневниках путешественники XIX и начала XX вв.

\section{Аржаан Булук в исторических документах}

В путевых заметках путешественников, посещавших территорию Урянхайской земли в XIX и XX вв. имеется ряд упоминаний об этом водном источнике именно под названием Булук.

Упоминается аржаан Булук в дневниках путешествий 1879-1880 гг. Г. Н. Потанина «Очерки Северо-Западной Монголии» (Потанин, 1883: 583).

В рассказе И. Г. Сафьянова об отправке в 1913 г. тувинских верблюдов в Норвегию одним из пунктов следования назван Булук: «Пришлось гнать их (верблюдов. - H. О.) до Булука, оттуда до села Верхне-Усинского» (Ермолаев, 1980: 4). Также местность Булук указывается в рукописях И. Г. Сафьянова, изданных в 2012 г. (Сафьянов, 2012: 115, 220).

В дневнике путешествия, исполненного в 1889 г. по поручению Императорской академии наук и Императорского Русского Географического Общества «Очерки Урянхайской земли», в записи от 3 мая Н. Ф. Катанов пишет: «В 2 верстах от заведения мы увидели на правой стороне от Улу-Кема замерзшую речку Булук и несколько замерзших маленьких водопадов, находящихся близ Булука» (Катанов, 2011: 46). С записей Н. Ф. Катанова наглядно вырисовывается естественно-географическая особенность водного источника, т. е. путешественник застал период образовавшегося за зимний период наледи - ‘булука'.

«Путь наш лежал через Булук на Атамановский поселок», - писала К. Д. Минцлова в дневнике «Далекий край: Путешествие по Урянхайской земле» 
в 1914 г. (Минцлова, 1993: 32), описывая дорогу путешествия в юго-восточную часть Тувы, начатое с Белоцарска в сторону устья р. Элегест и далее верх по руслу данной реки.

В географических картах, составленных в разные годы XIX и начала XX вв. путешественниками, помечается местность Булук. Такое же название имел противоположный к аржаану Булук берег реки Енисей. Так, например, на карте, приложенной к книге английского путешественника Д. Каррутерса «Неведомая Монголия», немного юго-западнее от Белоцарска находим наименование Булук (Каррутерс, 2003: карта-вкладка).

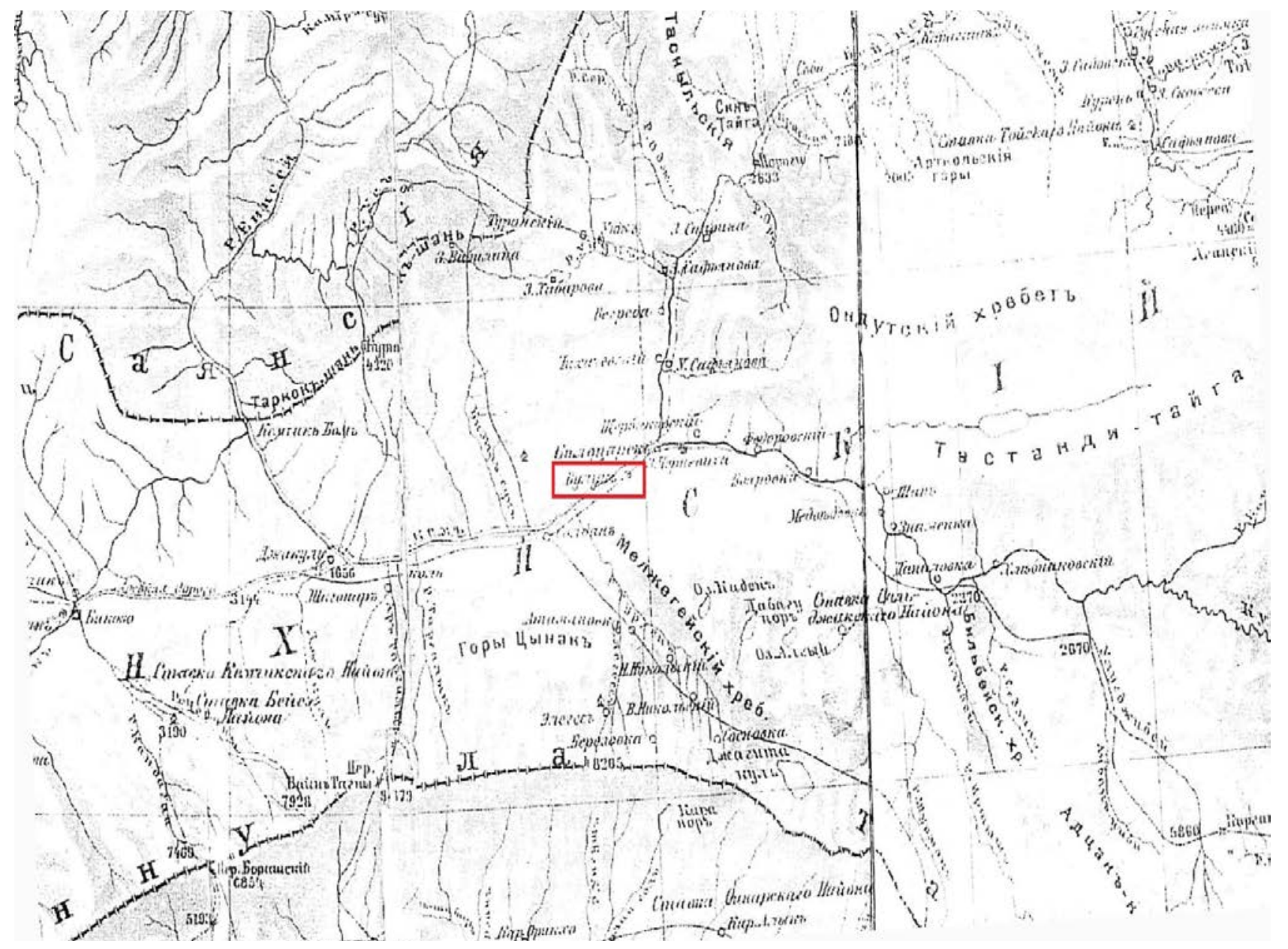

Рис. 2. Фрагмент карты из книги Д. Каррутерса 1910 г. (Каррутерс, 2003: карта-вкладка).

Pic. 2. A map fragment from a 1910 book by D. Carruthers (Carruthers, 2003: fold-in map).

Карту Урянхайского края съёмки 1886-1891 гг. с исправлениями границ 1911-1919 гг. мы встречаем в книге В. Н. Устиновского «Тува. Знаки почтовой оплаты». В этой карте указан поселок, название которого происходит от названия водного источника Булук (Устиновский, 2000: карта-вкладка). 


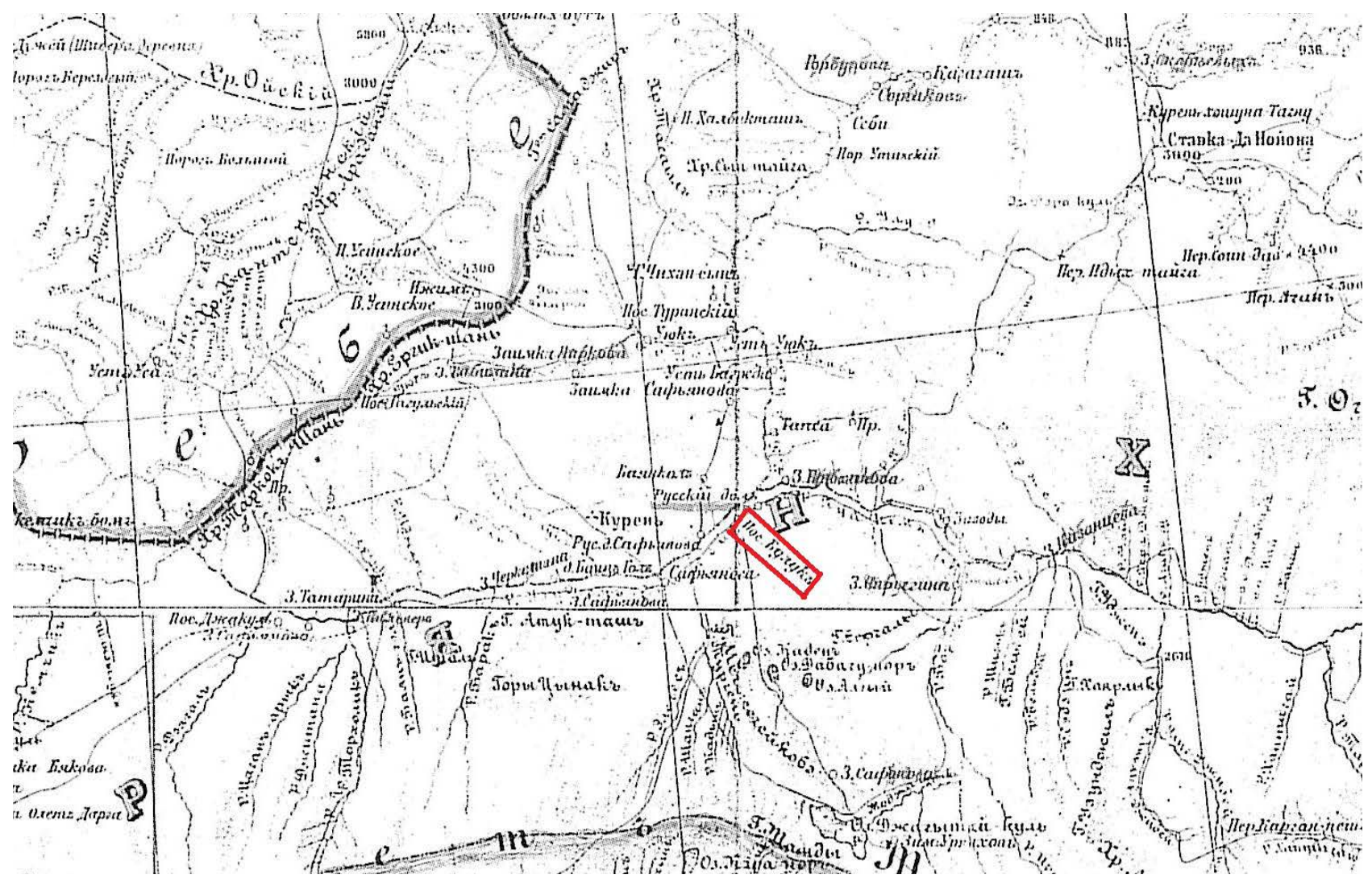

Рис. 3. Фрагмент карты из книги В. Н. Устиновского (Устиновский, 2000: карта-вкладка). Pic. 3. A map fragment from a book by V. N. Ustinovsky (Ustinovsky, 2000: fold-in map).

\section{Уважение к традищиям}

Как отмечал член Всесоюзного географического общества В. Пивторак, «в большинстве случаев русские путешественники, где бы они ни делали открытия, оставляли за географическими объектами местные имена, проявляя этим самым уважение к народам, населяющим эти места» (Пивторак, 1960: 3). Он отмечает меткость тувинского народа при даче того или иного названия различным географическим объектам. В частности, «указывают на географические связи объектов с другими природными факторами, многие названия характеризуют физико-географические особенности данного объекта. Другие названия указывают на богатства природы (недр, растительности или животного мира)» (там же).

Название, которое появилось у аржаана в 2004 г. - Кундустуг, по нашему мнению, не передает ни естественно-географическую, ни гидрологическую, ни биологическую и ни ландшафтную особенность данного источника.

Что оно означает и почему появилось? В тюркских языках, в том числе и тувинском, слово кундус означает ‘бобр’. 


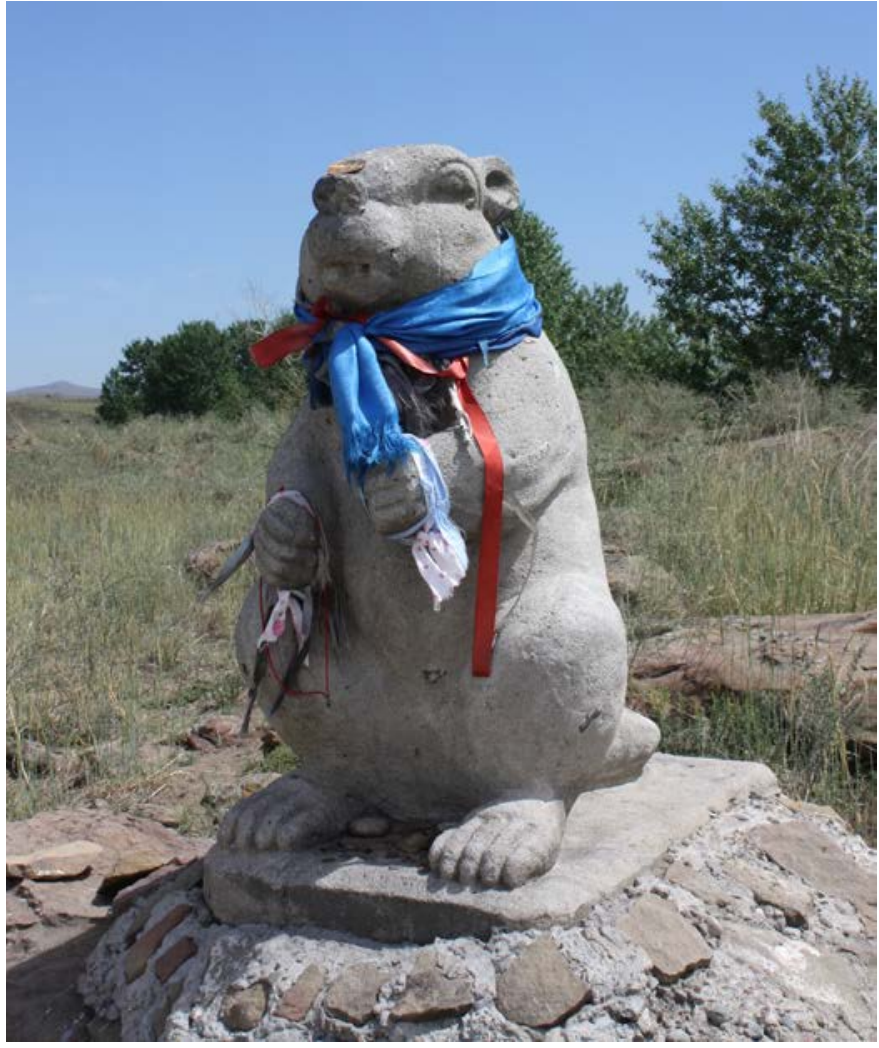

Рис. 4. Скульптура бобра, установленная на территории аржаана. Фото А. С. Папына, 2010 г. Pic. 4. A sculpture of a beaver, erected on the premises of the arzhaan, photo by A. Papyn, 2010.

Некоторые утверждают, что в прибрежных водах Енисея в районе аржаана обитали и обитают бобры. Этот довод сразу опровергается мнением биологов о том, что «бобры поселяются по берегам медленно текущих лесных рек, стариц и озёр, избегая широких и быстро текущих рек, а также промерзающих до дна водоёмов. Важно наличие у водоема пойменной древесно-кустарниковой растительности из мягких лиственных пород (ивы, тополя, осины), а также обилие водной и прибрежной травянистой растительности, составляющей их рацион» (Жизнь животных, 1989: 200).

В той части реки, куда стекают воды аржаана Булук, протекает основное русло реки Улуг-Хема, и потому водный поток набирает стремительность, а ее берега каменисты и кряжисты. Такие места, тем более скалистые, не могут быть местом обитания для бобров.

Известный местный краевед Василий Уйнукай и другие, по данным нашего опроса местных жителей в 2011 г., как только узнали о переименовании аржаана на Кундустуг, высказали свое несогласие тем, что изменили историческое название водного источника, являвшегося украшением их родовой местности. Подобное же мнение, как мы выяснили в то же время, выразили потомки чабанов, проживавших по Биче-Баян-Колу.

Но, к сожалению, в 2004 г. те, кто переименовали аржаан Булук, пренебрегли существующей традицией. Кроме того, в 2004 г. при присвоении нового названия аржаану не были соблюдены и законодательные нормы. В статье 6.1 Федерального закона № 152-Ф3 «О наименованиях географических объектов» от 18 декабря 1997 г., действующем в данное время, говорится об «опросе населения соответствующих территорий, опроса краеведов и других специалистов» (Федеральный ..., Электр. ресурс) при отсутствии существующих нормативных правовых актов и других источников, касающихся названия объекта, что не было сделано. В самом Положении «О статусе комплекса аржаана “Кундустуг”, утвержденном совместным постановлением мэра г. Кызыла 
и Главой администрации Кызылского кожууна № 1037 от 19 августа 2004 г. (Положение ..., 2004) не указаны нормативные правовые акты, статистические данные, данные официальных картографических и справочных изданий и иные источники, подтверждающие название Кундустуг.

В результате опроса в 2011 г. местных жителей с. Ээрбек и чабанов местности Биче-Баян-Кол и изучения газет Тувы за 2000-2004 гг. нами были сделаны следующие выводы. Во-первых, за год до переименования аржаана в Кундустуг в 2003 г. была публикация В. Уйнукая в газете «Тыва Республика», где краевед рассказывает о местностях, расположенных вокруг г. Кызыла (Уйнукай, 2003: 3). Отметим, что первым в этой публикации автор пишет об исследуемом нами аржаане, приводя его исконное название Булук. Также уточним, что данная публикация В. Уйнукай не предваряла предстоящие события 2004 г., связанные с этим аржааном. Во-вторых, перед переименованием аржаана в 2004 г. никакой работы по выяснению исконного названия водного источника - аржаана среди местного населения никем не проводилась. В-третьих, первые упоминания о водном источнике под новым названием Кундустуг появились только 21 августа 2004 г., т. е. тогда, когда уже состоялось официальное открытие облагороженной территории аржаана. В-четвертых, о данном новом переименовании местные жители узнали только после состоявшегося открытия. В-пятых, отдельные жители с. Ээрбек, как нам сообщила информатор Е.А. Опей-оол, местная жительница с. Ээрбек Кызылского кожууна ${ }^{1}$, услышав название Кундустуг, подумали, что это открыли и назвали Кундустугом другой аржаан, а не тот, которого они знали как Булук.

Историческое название аржаана Булук является образующей основой для нескольких микротопонимов - Булук кыры, Булук үстү и Булук адаа. Кроме того, существовавший в XIX в. русский поселок, находящийся на левом берегу Енисея напротив аржаана назывался также Булуком. Осенняя стоянка семьи Сандый находится в 2-3-х километрах к северу-западу от Булука (это местечко называется Булук кыры - 'Над Булуком'), верх по течению Енисея от аржаана, где располагаются чабанские стоянки, называется Булук үстү ('Верховье Булука') и соответственно вниз по течению Енисея - Булук адаа ('Низовье Булука').

Нет человека, который не имел бы свою малую родину, которая олицетворяет собой, как говорил профессор Ш. Ч. Сат: «... совокупность всех географических названий ограниченной местности:территории одногопоселка,речки,бригады. Для кочевников и охотников микротопонимия имела исключительно важное практическое значение. Каждый бугорок, лог, впадина, дорога, пастбище, речка, брод, возвышенность, холмы в сферах кочевий и охоты аала имели свои названия. ...» (Сат, 1970: 4). Помимо этого, малая родина и все, что с ним связано - для тувинцев священны. Для ээрбекцев и биче-баян-кольцев аржаан

${ }^{1}$ Запись сделана в 2011 г. Хранится в личном архиве автора статьи. 
Булук тоже имеет огромное значение. Старцы наставляют, что духи местности могут покинуть те места, которых они призваны охранять, если люди будут относиться неуважительно к этим культовым и священным объектам. И факт переименования Булука в Кундустуг воспринимается местными жителями, как пример пренебрежительного отношения к святостям народа, живущего на данной местности.

\section{Заключение}

В настоящее время аржаан, известный под названием Кундустуг, стал одним из знаковых и часто посещаемых мест в Туве, в Кызыле. Но несмотря на то, что название Кундустуг стало популярным, местные жители ведут работу по восстановлению исконного названия аржаана. Это связано и с их желанием восстановить справедливость, отдать дань почтения тому, что было именовано предками, а также с перспективными задачами. Поскольку строительство железной дороги, которая соединит Туву с Россией (через Красноярский край), считается решенным делом будущего, место рядом с аржааном предусмотрено для одной из железнодорожных станций. Это означает, что древний топоним Булук имеет перспективы войти и в железнодорожные наименования.

Жители с. Ээрбек выступили с инициативой о восстановлении исконного исторического названия аржаана Булук. В апреле 2011 г. они провели собрание, на котором составили обращение к властям сумона Ээрбек и Кызылского кожууна с подписями населения ${ }^{1}$. Также при участии автора настоящей статьи состоялись встречи местных жителей с учеными и представителями государственных служб. После сбора подписей и других документальных источников по данному вопросу в этом же году была проведена встреча с учеными Тувинского института комплексного освоения природных ресурсов СО РАН. Ученые, отмечая достоверность собранных к тому времени сведений и рассказов местных жителей по исконному названию аржаана Булук, выразили свою поддержку в пользу этого названия. В 2012 г. жители с. Ээрбек обратились в Службу по охране объектов культурного наследия (памятников истории и культуры) Республики Тыва о сложившейся ситуации с исконным названием аржаана Булук.

26 сентября 2013 г., после письменного обращения почетного гражданина г. Кызыла, известного писателя и журналиста Республики Тыва К.-К. К. Чооду к Главе Республики Тыва - Председателю Правительства Республики Тыва Ш. В. Кара-оолу о восстановлении исторических названий горы Тогэ в ПийХемском кожууне и аржаана Булук в Кызылском кожууне, прошло совещание

\footnotetext{
${ }^{1}$ Заявление жителей с. Ээрбек председателю сумона Ээрбек Кызылского кожууна о переименовании аржаана «Кундустуг» на историческое прежнее название «Булук» от 20.04.2011 г. хранится в текущем архиве администрации сумона Ээрбек Кызылского кожууна.
} 
под руководством заместителя Председателя Правительства Республики Тыва по вопросу восстановления исторических наименований горы Төгэ и аржаана Булук. В совещании приняли участие сотрудники Тувинского института гуманитарных исследований (прежнее название Тувинского института гуманитарных и прикладных социально-экономических исследований), Службы по охране объектов культурного наследия (памятников истории и культуры) Республики Тыва, Научно-образовательного центра «Тюркология» при Тувинском государственном университете и представителей администраций Пий-Хемского и Кызылского кожуунов. Также на этом совещании принимали участие уроженец местечка Биче-Баян-Кол Д. С. Дотпаа и автор настоящей статьи, озвучившая информацию об исконном названии аржаана Булук с предоставлением исторических документальных источников.

В итоге после предоставленной информации с источниками и выступлений руководителя службы, К.-К. К. Чооду и Д. С. Дотпаа на совещании было вынесено решение о восстановлении исконного названия аржаана Булук и в качестве исполнителей были определены администрации сумона Ээрбек и Кызылского кожууна.

К сожалению, с того времени ситуация так и не разрешилась. Соответствующих мер принято не было, несмотря на неоднократные обращения жителей, призывавших чиновников к исполнению данного решения. Мы полагаем, что исконное название должно быть в любом случае возвращено.

\section{СПИСОК ЛИТЕРАТУРЫ}

Федеральный закон от 18 декабря 1997 г. № 152-Ф3 «О наименованиях географических объектов» (с изменениями и дополнениями) [Электронный pecypc]// Система Гарант. URL: http://base.garant.ru/12106462/ (дата обращения: 10.07.2018).

Жизнь животных (1989) : в 7 т. / редкол. В. Е. Соколов (гл. ред.) и др. 2-е изд., перераб. М. : Просвещение. Т. 7. Млекопитающие / под. ред. В. Е. Соколова. 558 с.

Каррутерс, Д. (2003) Неведомая Монголия. Т. 1. Урянхайский край. Кызыл : Тувинское книжное изд-во. 341 с.

Катанов, Н. Ф. (2011) Очерки Урянхайской земли: Дневник путешествия, исполненного в 1889 году по поручению Императорской Академии Наук и Императорского Русского Географического Общества. Кызыл : ООО «Кооператив «Журналист». 384 с.

Маннай-оол, М. Х. (2004) Тувинцы: Происхождение и формирование этноса. Новосибирск : Наука. 166 с.

Минцлова, К. Д. (1993) Далёкій край: Путешествіе по Урянхайской земле. Кызыл : Новости Тувы. 128 с. 
Ондар, Б. К. (2007) Топонимический словарь Тувы. 2-е изд., перераб. Кызыл : Тувинское книжное изд-во. 550 с.

Пивторак, В. (1960) О карте Тувы // Тувинская правда. 14 мая. С. 3.

Положение «О статусе аржаана «Кундустуг» (2004) // Вести Кызыла. № 34. С. 3.

Потанин, Г. Н. (1883) Очерки Северо-Западной Монголии: Вып. IV. СПб. : Типография В. Киршбаума. 2196 с.

Сат, Ш. Ч. (1970) Заметки по топонимике // Тувинская правда. 20 сентября. С. 4.

Сафьянов, И. Г. (2012) Тува в прошлом : в 2 т. М. : б/и. Т. 1. Художественное творчество тувинского народа. Фотоархив: К 90-летию Тувинской Народной Республики. 232 с.

Татаринцев, Б. И. (2000) Этимологический словарь тувинского языка. Новосибирск : Наука. Т. 1. А-Б. 341 с.

Толковый словарь тувинского языка (2003) / под ред. Д. А. Монгуша. Новосибирск : Наука. Т. 1. А-Й. 599 с.

Тувинско-русский словарь (1968) / под ред. Э. Р. Тенишева. М. : Советская энциклопедия. 646 с.

Уйнукай В. (2003) Кызылды долгандыр чүү барыл? // Тыва Республика № 30. С. 3. (На тув. яз.).

Уйнукай В. (2004) Перекресток с давних времен // Вести Кызыла. № 39. С. 6.

Устиновский, В. Н. (2000) Тува. Знаки почтовой оплаты. М. : ООО «Дом печати «Столичный бизнес». 204 с.

Дата поступления: 31.05.2018 2.

\section{REFERENCES}

Federal'nyi zakon ot 18 dekabria 1997 g. N 152-FZ "O naimenovaniiakh geograficheskikh ob"ektov" (s izmeneniiami i dopolneniiami) [The federal law of December 18, 1997 no. 152-FZ "About names of geographical objects" (with changes and additions)]. Sistema Garant [online] Available at: http://base.garant.ru/12106462/ (access date: 10.07.2018) (In Russ.).

Zhizn'zhivotnykh [Life of animals] (1989) : in 7 vols / Editorial board: V. E. Sokolov (editor-in-chief) et al. 2nd ed. Moscow, Prosveshchenie. Vol. 7. Mlekopitaiushchie [Mammals] / ed. by V. E. Sokolov. 558 p. (In Russ.).

Carruthers, D. (2003) Nevedomaia Mongoliia. Vol. 1. Uriankhaiskii krai [Unknown Mongolia. Vol. 1. Uryankhaysky krai]. Kyzyl, Tuvinskoe knizhnoe izd-vo. 341 p. (In Russ.) 
Katanov, N. F. (2011) Ocherki Uriankhaiskoi zemli: Dnevnik puteshestviia, ispolnennogo $v 1889$ godu po porucheniiu Imperatorskoi Akademii Nauk i Imperatorskogo Russkogo Geograficheskogo Obshchestva [Sketches of the Uryankhaysky krai: The diary of the journey made in 1889 at the request of Imperial Academy of Sciences and the Imperial Russian Geographical Society]. Kyzyl, OOO «Kooperativ «Zhurnalist». 384 p. (In Russ.)

Mannai-ool, M. X. (2004) Tuvintsy: Proiskhozhdenie i formirovanie etnosa [Tuvans: Origin and formation of an ethnicity]. Novosibirsk, Nauka Publ. 166 p. (In Russ.).

Mintslova, K. D. (1993) Dalekii krai: Puteshestvie po Uriankhaiskoi zemle [Strange lands: Travels in the Uryankhaysky krai]. Kyzyl, Novosti Tuvy. 128 p. (In Russ.)

Ondar, B. K. (2007) Toponimicheskii slovar' Tuvy [A Toponymical dictionary of Tuva]. 2nd ed. Kyzyl, Tuvinskoe knizhnoe izd-vo. 550 p. (In Russ.)

Pivtorak, V. (1960) O karte Tuvy [On a map of Tuva]. Tuvinskaia pravda, 14 May, p. 3. (In Russ.)

Polozhenie «O statuse arzhaana «Kundustug» [Regulation "On the status of an arzhaan of "Kundustug"] (2004). Vesti Kyzyla, no. 34, p. 3. (In Russ.)

Potanin, G. N. (1883) Ocherki Severo-Zapadnoi Mongolii [Sketches of Northwest Mongolia]. St. Peterburg, Tipografiia V. Kirshbauma. Vol. IV. 2196 p. (In Russ.)

Sat, Sh. Ch. (1970) Zametki po toponimike [Notes on toponymics]. Tuvinskaia pravda, 20 September, p. 4. (In Russ.)

Saf'ianov, I. G. (2012) Tuva v proshlom [Tuva in the past]: in 2 vols. Moscow. Vol. 1. Xudozhestvennoe tvorchestvo tuvinskogo naroda. Fotoarkhiv: K 90-letiiu Tuvinskoi Narodnoi Respubliki [Art of the Tuvan people. Photoarchive: To the 90 anniversary of the Tuva People's Republic]. 232 p. (In Russ.)

Tatarintsev, B. I. (2000) Etimologicheskii slovar' tuvinskogo iazyka [Etymological dictionary of the Tuva language]. Novosibirsk, Nauka Publ. Vol. 1. A-B. 341 p. (In Russ.)

Tolkovyi slovar' tuvinskogo iazyka [Explanatory dictionary of the Tuva language]. (2003) / ed. by D. A. Mongush. Novosibirsk, Nauka Publ. Vol. 1. A-I. 599 p. (In Russ.)

Tuvinsko-russkii slovar' [A Tuvan-Russian dictionary] (1968) / ed. by E. R. Tenisheva. Moscow, Sovetskaia entsiklopediia. 646 p. (In Russ.)

Uinukai, V. (2003) Kyzyldy dolgandyr chyY baryl? [What lies in vicinities of Kyzyl?]. Tyva Respublika, no. 30, p. 3. (In Tuv.)

Uinukai, V. (2004) Perekrestok s davnikh vremen [A long-time road intersection]. Vesti Kyzyla, no. 39, p. 6. (In Russ.)

Ustinovskii, V. N. (2000) Tuva. Znaki pochtovoi oplaty [Tuva. Indicia]. Moscow, OOO «Dom pechati «Stolichnyi biznes». 204 p. (In Russ.) 


\section{Для цитирования:}

Очур Н. М. Исконное название аржаана Кундустуг - Булук [Электронный ресурс]// Новые исследования Тувы. 2018, № 3. URL: https://nit.tuva.asia/nit/article/ view/794 (дата обращения: дд.мМ.гг.). DOI: 10.25178/nit.2018.3.10

\section{For citation:}

Ochur N. M. Buluk as the original name of arzhaan Kundustug. The New Research of Tuva, 2018, no. 3 [on-line] Available at: https://nit.tuva.asia/nit/article/view/794 (accessed:...). DOI: 10.25178/nit.2018.3.10 